\title{
Prevention, Early Detection of Premalignant Lesions
}

National Cancer Institute

\section{Source}

National Cancer Institute. Prevention, Early Detection of Premalignant Lesions. NCI

Thesaurus. Code C15842.

A procedure that includes screening, diet and behavioral adjustments to prevent and/or detect the transformation of normal cells into cancerous lesions. 